\title{
Synthesis of Deuterated Surrogate Standards for the Analysis of Legally Regulated Substances in Cosmetics
}

\author{
Beatriz Fariña, ${ }^{\mathrm{a}}$ Carlos González, ${ }^{\mathrm{a}}$ Manuel Lolo, ${ }^{\mathrm{b}}$ and F. Javier Sardina*a \\ ${ }^{a}$ Centro Singular de Investigación en Química Biolóxica e Materiais Moleculares (CIQUS) and \\ Departamento de Química Orgánica, Universidade de Santiago de Compostela, 15782 Santiago \\ de Compostela, Spain
}

${ }^{\mathrm{b}}$ Applied Mass Spectrometry Laboratory, SLU (AMSLab). Avda. Benigno Rivera, 56, 27003 Lugo, Spain

*Corresponding author: javier.sardina@usc.es

\begin{abstract}
The presence of harmful substances in cosmetic products is regulated in most countries. In the European Union the Regulation (EC) No. 1223/2009 lays down the requirements for the marketing of cosmetic products. Among others, important families of compounds restricted in the Regulation are musks, allergenic fragrances and phthalates. To ensure product safety, improved analytical methods capable of reliably and reproducibly detecting the presence of traces of prohibited and/or restricted ingredients in raw materials and finished products are required.

For the continuous improvement of the reliability of the analytical methods developed to check the compliance of cosmetic products with the Regulation, the use of appropriate surrogate standards or contaminants (substances that are added to the samples to be analyzed to establish the recovery and the reproducibility of the quantification of the analytes) are of utmost importance. One of the best kinds of surrogate standards are isotopically labeled analogs of the analytes of interest. In this work, several synthetic methods have been developed to prepare isotopically labeled analogs of atranol, chloroatranol, di-n-octylphthalate, musk xylene, and musk ambrette, which are restricted substances in cosmetic articles.
\end{abstract}

\footnotetext{
${ }^{1}$ Current address: Sigillum Knowledge Solutions S.L. Calle Restollal, 32, 15702 Santiago de Compostela, Spain (carlos.gonzalez@sigillumks.com)
} 


\section{Introduction}

The contents of substances hazardous to human health in consumer products are regulated by most countries and supranational entities. For cosmetic products and personal care articles, Regulation (EC) No. 1223/2009 lays down the requirements for the marketing of such products in the European Union. This Regulation harmonises EU rules in order to achieve the free movement of cosmetic products and to ensure a high level of protection of human health. ${ }^{2}$

From a chemical perspective, a cosmetic product is a mixture of substances. Due to their nature and their forms of application and use, these products have a high degree of interaction with the skin and/or mucous membranes of consumers. Therefore, and with the aim of safeguarding the safety of final products, the Regulation includes a number of restrictions on the presence of certain harmful substances in cosmetic products, because of the risks they may pose to human health.

Among the many prohibited and restricted substances (more than 1700 in total) in this Regulation, three very relevant groups of compounds should be highlited due to the level of hazard that they pose: synthetic fragrances (musks), allergenic fragrances and phthalates. Examples of representative structures of these three types of coumpouds are shown in the following figure:<smiles>[R]c1c([R])c([N+](=O)[O-])c([R])c([R])c1[N+](=O)[O-]</smiles>

Nitromusks<smiles>[R]c1c(C)cc(O)c(C=O)c1O</smiles>

Moss extracts<smiles>[R2]OC(=O)c1ccccc1C(=O)O[R]</smiles>

Phthalates

Figure 1 Representative chemical structures of the three groups of regulated substances in cosmetic products studied in this paper

\footnotetext{
${ }^{2}$ Regulation (EC) No. 1223/2009 of the European Parliament and of the Council of 30 November 2009 on cosmetic products. Off J Eur Union 2009: L342: 59-209. Accessible at https://eur-lex.europa.eu/legalcontent/es/ALL/?uri=CELEX\%3A32009R1223. Accessed October 20, 2020.
} 


\subsection{Musks}

Musks are a group of chemicals used in perfumery which posses a penetrating and persistent odor. They are valuable compounds, not only for their own odor, but also for their binding properties of other more volatile substances present in the formulation of the cosmetic.

Natural musks comes from the exocrine glands of the musk deer (Moschus moschiferus) and consists of a complex mixture of substances such as ketones, lactones and macrocyclic alcohols, as well as pyridine derivatives, which provide their characteristic odor. Of these substances, the most important for the cosmetic industry has been the muscone (Figure 2). ${ }^{3}$

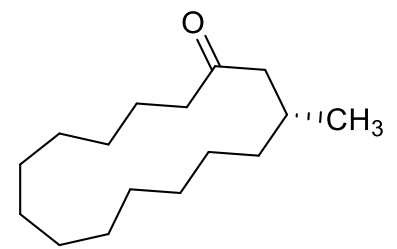

Figure 2 Chemical structure of the muscone

Synthetic musks were introduced in order to replace the natural ones. In 1888, A. Baur developed the first synthetic musk and around 1950 there were already available a large number of these products with a wide range of odors, at significantly lower prices than natural musks. ${ }^{4}$ The olfactory and fastening properties of synthetic musks are similar to those of natural ones.

\footnotetext{
3 a) Knopff, O.; Kuhne, J.; Fehr, C. Enantioselective Intramolecular Aldol Addition/Dehydration Reaction of a Macrocyclic Diketone: Synthesis of the Musk Odorants (R)-Muscone and (R,Z)-5-Muscenone. Angew. Chemie - Int. Ed. 2007, 46, 1307-1310. https://doi.org/10.1002/anie.200604518.Esta b) Ruzicka, L. Helv. Chim. Acta 1926, 9, 715729.

${ }^{4}$ Marchal, M.; Beltran, J. Determination of Synthetic Musk Fragrances. Int. J. Environ. Anal. Chem. 2016, 96, 12131246. https://doi.org/10.1080/03067319.2016.1249479.
} 
Musks can be divided into four groups, depending on their chemical structures: nitro, polycyclics, macrocyclics and alicyclics. ${ }^{5}$ The following figure shows some representative structures of these substances.
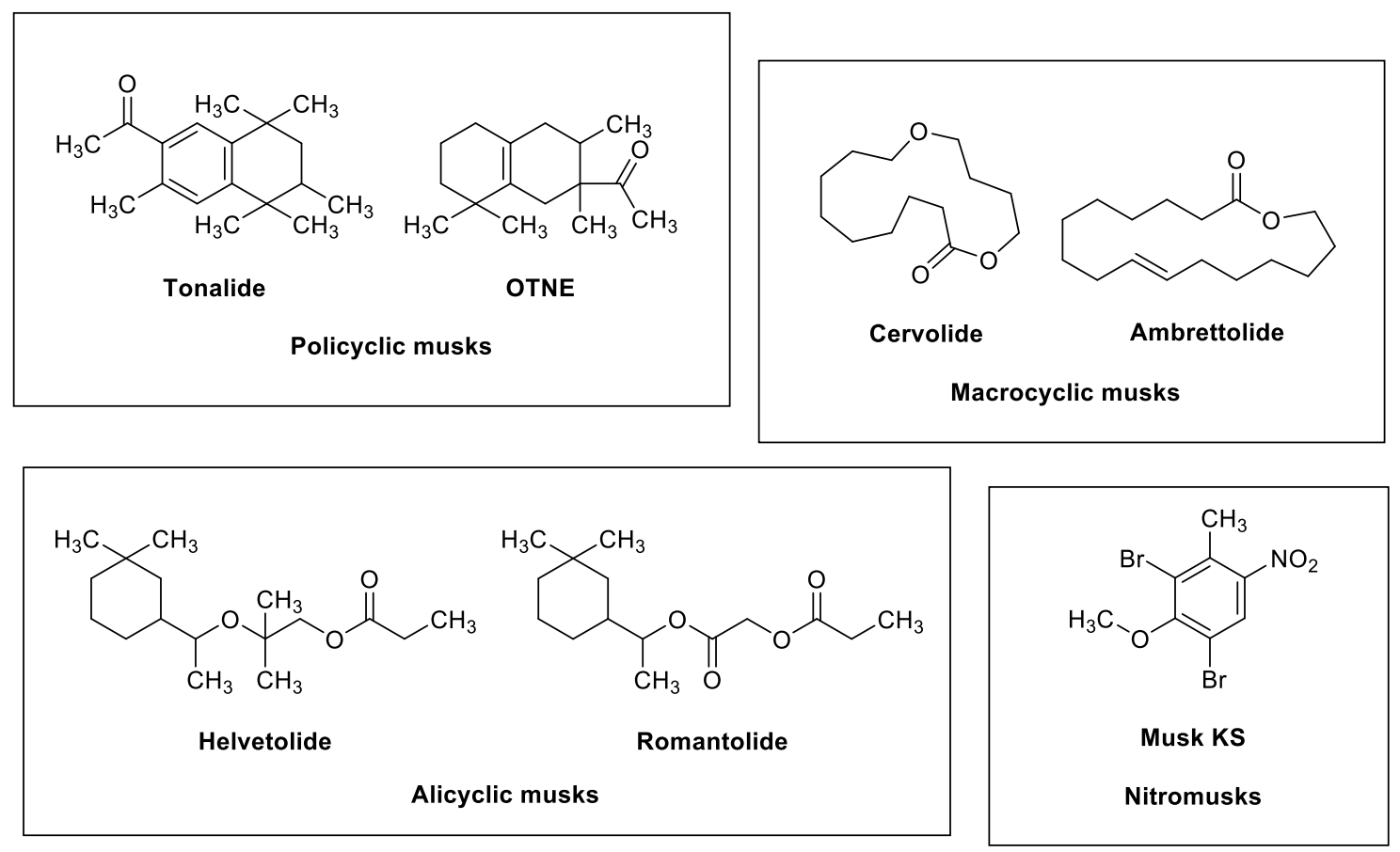

Figure 3 Representative chemical structures of different classes of musks

Polycyclic and nitro musks are predominant in terms of production volume, accounting for $61 \%$ and $35 \%$, respectively, of the total amount of synthetic musks produced in the world. ${ }^{6}$

\section{Synthetic nitro musks}

Due to ease of their preparation and low production costs, nitrogenous musks (or nitromusks) have been used as fragrances in the industrial production of many products, such as soaps, colognes, detergents, softeners, personal care products and others. In

\footnotetext{
5 Tumová, J.; Šauer, P.; Golovko, O.; Koba Ucun, O.; Grabic, R.; Máchová, J.; Kocour Kroupová, H. Effect of Polycyclic Musk Compounds on Aquatic Organisms: A Critical Literature Review Supplemented by Own Data. Sci. Total Environ. 2019, 651, 2235-2246. https://doi.org/10.1016/j.scitotenv.2018.10.028.

${ }^{6}$ Nakata, H.; Hinosaka, M.; Yanagimoto, H. Macrocyclic-, Polycyclic-, and Nitro Musks in Cosmetics, Household Commodities and Indoor Dusts Collected from Japan: Implications for Their Human Exposure. Ecotoxicol. Environ. Saf. 2015, 111, 248-255. https://doi.org/10.1016/j.ecoenv.2014.09.032.
} 
addition, some were also used as food additives, air fresheners, chewing tobacco, fishing baits and other types of products (such as herbicides and explosives). ${ }^{7}$

Nitromusks consist of substituted nitrobenzene derivatives that incorporate alkyl, ketone or methoxy groups into their structures. They were discovered in the late 19th century, but by the mid-1990s their use and production began to be drastically reduced, due to the adverse health effects associated with these substances. ${ }^{7,8}$

Examples of compounds included in the nitrogen musk family are: musk ketone (MK), musk ambrette (MA), musk moskene (MM), musk tibetene (MT), musk xylene (MX), musk alpha and musk KS. Their structures, very different from those of natural musks, are shown in the following figure. ${ }^{4,9}$<smiles>COc1c(C(C)(C)C)cc([N+](=O)[O-])c(C)c1[N+](=O)[O-]</smiles>

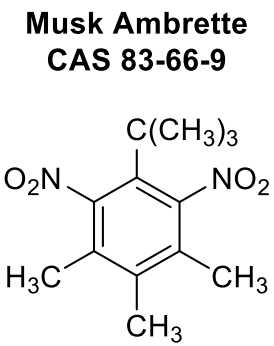

Musk Tibetene CAS 145-39-1<smiles>CC(=O)c1cc([N+](=O)[O-])c(C(C)(C)C)c([N+](=O)[O-])c1</smiles>

Musk Ketone

CAS 81-14-1<smiles>Cc1c([N+](=O)[O-])c(C)c([N+](=O)[O-])c(C(C)(C)C)c1[N+](=O)[O-]</smiles>

\section{Musk Xylene}

CAS 81-15-2<smiles>COc1c(Br)c(C)c(C(C)(C)C)c([N+](=O)[O-])c1Br</smiles>

Musk Alpha

CAS 63697-53-0<smiles>Cc1c([N+](=O)[O-])cc2c(c1[N+](=O)[O-])C(C)(C)CC2(C)C</smiles>

$$
\text { Musk Moskene }
$$

CAS 116-66-5<smiles>COc1c(Br)cc([N+](=O)[O-])c(C)c1Br</smiles>

Musk KS

CAS 62265-99-0

Figure 4 Chemical structures of representative nitromusks

\footnotetext{
${ }^{7}$ Schmeiser, H. H.; Gminski, R.; Mersch-Sundermann, V. Evaluation of Health Risks Caused by Musk Ketone. Int. J. Hyg. Environ. Health 2001, 203, 293-299. https://doi.org/10.1078/1438-4639-00047.

${ }^{8}$ Rimkus, G. Polycyclic musk fragrances in the aquatic environment. Toxicol. Lett. 1999, 111, 37-56. https://doi.org/10.1016/S0378-4274(99)00191-5

${ }^{9}$ Sommer, C. The Role of Musk and Musk Compounds in the Fragrance Industry. Handb. Environ. Chem. 2004, 3, 116. https://doi.org/10.1007/b14130.
} 
The most widely used nitromusks have been musks ketone and xylene, mainly as additives in detergents, cosmetics and fragrances. As an example of the prevalence of their use, suffice it to note that, in a 2011 work by Lu and collaborators, which assessed the presence and levels of synthetic musks in personal care products in China, musk ketone and musk xylene were found to be present in more than $50 \%$ of the articles analyzed. ${ }^{10,11,12}$

The main source of exposure to synthetic musks is caused by the use of scented products, both for personal care and household use. There are three main routes of exposure: inhalation, ingestion and dermal absorption, the latter being the most important of all. ${ }^{13}$

Acute toxicity of nitromusks in humans is low. However, in the context of the accumulation of substances in adipose tissue and excretion in breast milk, the issue of chronic toxicity is of great importance. ${ }^{11,14,15}$ In addition, some studies reveal that synthetic musks are potentially mutagenic and genotoxic, and they induce the cytochrome P450 enzyme. ${ }^{6}$ Finally, they can also cause respiratory toxicity and dermal irritation. ${ }^{16}$

In China and India these substances are still produced, and in the United States they are also used in non-cosmetic compounds that have not been reformulated. In Europe, in

\footnotetext{
10 Taylor, K.; Weisskopf, M.; Shine, J. Human Exposure to Nitro Musks and the Evaluation of Their Potential Toxicity: An Overview. Environ Health, 2014, 13, 1-7. https://doi.org/10.1186/1476-069X-13-14.

${ }^{11}$ Ippen, H. Nitro Musk. Int Arch Occup Environ Health 1994, 66, 283-285.https://doi.org/10.1007/BF00454368

${ }^{12}$ Lu, Y.; Yuan, T.; Wang, W.; Kannan, K. Concentrations and Assessment of Exposure to Siloxanes and Synthetic Musks in Personal Care Products from China. Environ. Pollut. 2011, 159 (12), 3522-3528. https://doi.org/10.1016/j.envpol.2011.08.015.

${ }^{13}$ Hutter, H. P.; Wallner, P.; Hartl, W.; Uhl, M.; Lorbeer, G.; Gminski, R.; Mersch-Sundermann, V.; Kundi, M. Higher Blood Concentrations of Synthetic Musks in Women above Fifty Years than in Younger Women. Int. J. Hyg. Environ. Health 2010, 213, 124-130. https://doi.org/10.1016/j.ijheh.2009.12.002.

${ }^{14}$ Rimkus, G. G.; Wolf, M. Polycyclic Musk Fragrances in Human Adipose Tissue and Human Milk. Chemosphere 1996, 33, 2033-2043. https://doi.org/10.1016/0045-6535(96)00321-9.

${ }^{15}$ Wang, H.; Zhang, J.; Gao, F.; Yang, Y.; Duan, H.; Wu, Y.; Berset, J. D.; Shao, B. Simultaneous Analysis of Synthetic Musks and Triclosan in Human Breast Milk by Gas Chromatography Tandem Mass Spectrometry. J. Chromatogr. B 2011, 879, 1861-1869. https://doi.org/10.1016/j.jchromb.2011.04.036.

${ }^{16}$ Ramos, S.; Homem, V.; Santos, L. Analytical Methodology to Screen UV-Filters and Synthetic Musk Compounds in Market Tomatoes. Chemosphere 2020, 238, 124605. https://doi.org/10.1016/j.chemosphere.2019.124605.
} 
2007, it was estimated that the presence of nitromusks in such products reached $5 \%$ of the products accessible on the market. ${ }^{17,18}$

Finally, despite their stability, these compounds can undergo transformations in the environment and in animals, leading to aminoderivates. These products can be even more problematic than the compounds from which they derive. ${ }^{19}$

\section{Musk xylene}

Due to its lipophilic nature and chemical stability, musk xylene has been detected in numerous matrices, such as air, water, residual sludge, sediments and bioorganisms. Consumption of fish and drinking water, as well as the use of personal care products and scented goods, could lead to human ingestion of this compound..$^{20,21}$

The metabolism of musk xylene has been described to occur through the hydroxylation of some substitutes and through partial reduction of nitro groups to amino. ${ }^{11}$ One of the metabolites of musk xylene, 1-tert-butyl-3,5-dimethyl-4-amino-2,6-dinitrobencene, has been shown to bind to hemoglobin and appear as a biotransformation product in urine. ${ }^{10,22}$ In 1997, musks xylene and ketone were included in the European Union's list of priority action chemicals, and in 1998 musk xylene was added to the corresponding list of the

\footnotetext{
17 Regueiro, J.; Llompart, M.; Garcia-Jares, C.; Garcia-Monteagudo, J. C.; Cela, R. Ultrasound-Assisted Emulsification-Microextraction of Emergent Contaminants and Pesticides in Environmental Waters. J. Chromatogr. A 2008, 1190, 27-38. https://doi.org/10.1016/j.chroma.2008.02.091

${ }^{18}$ Polo, M.; Garcia-Jares, C.; Llompart, M.; Cela, R. Optimization of a Sensitive Method for the Determination of Nitro Musk Fragrances in Waters by Solid-Phase Microextraction and Gas Chromatography with Micro Electron Capture Detection Using Factorial Experimental Design. Anal. Bioanal. Chem. 2007, 388, 1789-1798. https://doi.org/10.1007/s00216-007-1359-z.

19 Bester, K. Analysis of Musk Fragrances in Environmental Samples. J. Chromatogr. A 2009, 1216, 470-480. https://doi.org/10.1016/j.chroma.2008.08.093.

${ }^{20}$ Zhang, Y.; Huang, L.; Zhao, Y.; Hu, T. Musk Xylene Induces Malignant Transformation of Human Liver Cell Line L02 via Repressing the TGF- $\beta$ Signaling Pathway. Chemosphere 2017, 168, 1506-1514. https://doi.org/10.1016/j.chemosphere.2016.12.001.

${ }^{21}$ Garcia-Jares, C.; Regueiro, J.; Barro, R.; Dagnac, T.; Llompart, M. Analysis of Industrial Contaminants in Indoor Air. Part 2. Emergent Contaminants and Pesticides. 2009, 1216, 567-597. https://doi.org/10.1016/j.chroma.2008.10.020.

${ }^{22}$ Riedel, J.; Birner, G.; Dorp, C.; Neumann, H. G.; Dekant, W. Haemoglobin binding of a musk xylene metabolite in man. Xenobiotica 1999, 29, 573-582. https://doi.org/10.1080/004982599238399
} 
Oslo and Paris Commission (OSPARCOM). In the same year, the compound was proven to be a carcinogen in animal studies. ${ }^{18,21,23}$

In 2008, under the REACH regulation, the xylene musk was classified as a substance of very high concern (SVHC), being designated as very persistent and highly bioaccumulative. Regulation of the use of this compound in recent decades has led to a reduction of its environmental levels in some areas. ${ }^{20}$

Currently, the presence of musk xylene is limited through Regulation 1223/2009 in different cosmetic products to $1 \%$ in fine fragrances, $0.4 \%$ in cologne waters and $0.03 \%$ in other products.

\section{Musks ambrette}

Musk ambrette was tipically used in fragrances and was withdrawn from the market in the 1990s due to its neurotoxic effects, as well as its ability to cause photo-irritation and photo-allergy in humans. ${ }^{7,11,24}$

Studies have shown that consumption of this musk is associated with weakness in the hind legs of rats, as well as neuropathological changes in the brain, spinal cord and peripheral nerves. ${ }^{10,11}$

\section{Methods for musk analysis}

Several analytical methods have been developed for the identification and quantification of musks in a wide variety of environmental samples. All of the aforementioned musks can be analyzed by Gas-Mass Chromatography (GC-MS) and Tandem Mass Spectrometry (GC-MS-MS). Alternatively, nitromusks can also be detected by Gas Chromatography with Electron Capture Detector (GC-ECD) or Gas Chromatography with Atomic Emission Detector (GC-AED) (N line). ${ }^{18,21,25}$

\footnotetext{
${ }^{23}$ a) European Commission (1997) Commission regulation (EC) no 143/97 of 27 January of 1997 concerning the third list of priority substances as foreseen under Council regulation (EEC) no 793/93 (1997). Official journal no L 025, 28.113-114 b) OSPAR Background Document on Musk Xylene and Other Musks, OSPAR Commission, London, 2004.

24 Tokura, Y. Photoallergy. Expert. Rev. Dermatol 2009, 4, 263-270. https://doi.org/10.1586/edm.09.14

${ }^{25}$ Linkerhägner, M.; Stan, H. -J; Rimkus, G. Detection of Nitro Musks in Human Fat by Capillary Gas Chromatography with Atomic Emission Detection (AED) Using Programmed Temperature Vaporization (PTV). J. High Resolut. Chromatogr. 1994, 17, 821-826. https://doi.org/10.1002/jhrc.1240171204.
} 
Nevertheless, there is currently no official analysis protocol in place for the quantification of nitromusks in cosmetic products.

Dong's group analyzed creams by dilution in water/isopropanol, and SLE coupled with SPE followed by GC-MS/MS. ${ }^{26}$ The group of Lores, Jares and Llompart have developed several methods for the analysis of these substances: (a) for the simultaneous determination of various compounds in perfumes, diluting samples in ethyl acetate and injecting directly into a GC-MS system, ${ }^{27}$ (b) using a solid phase matrix dispersion and GC-MS for the determination of five nitromusks in different formulations of cosmetic products (creams, body lotions, shampoos and soaps), ${ }^{28}$ and, in 2018, (c) they used GCMS to analyze 50 cosmetic products (masks, lipsticks/eyes, eyelash extensions), using microwave-assisted extraction for sample preparation. ${ }^{29}$ For its part, in 2019, Tsai and coworkers analyzed 109 personal care products, by diluting them with water and carrying out SPME followed by GC-MS/MS. ${ }^{30}$

\subsection{Allergenic fragrances}

Allergenic fragrances are a group of chemicals associated with fragrances and classified as a potential cause of allergic reactions. A total of 26 substances of this kind are regulated in cosmetic products in Europe and are included in Annex III to Regulation (EC) No. $1223 / 2009$.

\footnotetext{
${ }^{26}$ Dong, H.; Tang, H.; Chen, D.; Xu, T.; Li, L. Analysis of 7 Synthetic Musks in Cream by Supported Liquid Extraction and Solid Phase Extraction Followed by GC-MS/MS. Talanta 2014, 120, 248-254. https://doi.org/10.1016/j.talanta.2013.11.086.

${ }^{27}$ Sanchez-Prado, L.; Llompart, M.; Lamas, J. P.; Garcia-Jares, C.; Lores, M. Multicomponent Analytical Methodology to Control Phthalates, Synthetic Musks, Fragrance Allergens and Preservatives in Perfumes. Talanta 2011, 85, 370379. https://doi.org/10.1016/j.talanta.2011.03.079.

${ }^{28}$ Llompart, M.; Celeiro, M.; Pablo Lamas, J.; Sanchez-Prado, L.; Lores, M.; Garcia-Jares, C. Analysis of Plasticizers and Synthetic Musks in Cosmetic and Personal Care Products by Matrix Solid-Phase Dispersion Gas ChromatographyMass Spectrometry. J. Chromatogr. A 2013, 1293, 10-19. https://doi.org/10.1016/j.chroma.2013.03.067.

${ }^{29}$ Lores, M.; Celeiro, M.; Rubio, L.; Llompart, M.; Garcia-Jares, C. Extreme Cosmetics and Borderline Products: An Analytical-Based Survey of European Regulation Compliance. Anal. Bioanal. Chem. 2018, 410 (27), 7085-7102. https://doi.org/10.1007/s00216-018-1312-3.

${ }^{30}$ Tseng, W. J.; Tsai, S. W. Assessment of Dermal Exposures for Synthetic Musks from Personal Care Products in Taiwan. Sci. Total Environ. 2019, 669, 160-167. https://doi.org/10.1016/j.scitotenv.2019.03.046.
} 


\section{Atranol and chloroatranol}

Of the aforementioned 26 allergenic fragances, two of them correspond to natural lichen extracts, oak extracts and tree moss extracts, which have a complex chemical composition. They are usually obtained by extraction of two species of lichens: Evernia prunastri and Pseudovernia furfuracea. ${ }^{31}$ Among the many compounds present in the extracts of these lichens are atranol and chloroatranol, which are very potent allergens.

These substances are not present in significant amounts in the natural form of the lichen, but instead are degradation products, formed by transesterification and decarboxylation of the depside lipids atranorin and chloroatranorin (Figure 5). ${ }^{32,33}$

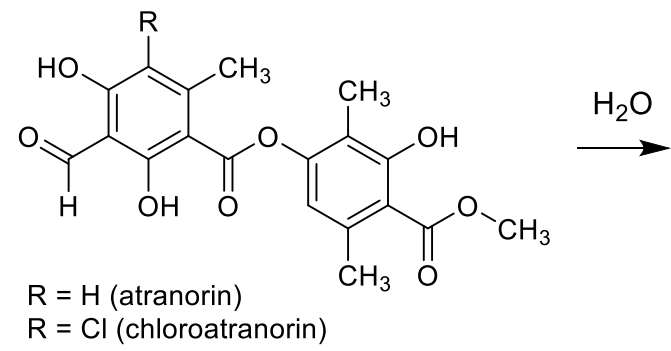<smiles>COC(=O)c1c(C)cc(O)c(C)c1O</smiles><smiles>[Y]C(=O)[O-]</smiles><smiles>[R]c1c(C)cc(O)c(C=O)c1O</smiles>

$\mathrm{R}=\mathrm{H}$ (atranol) $\mathrm{R}=\mathrm{Cl}$ (chloroatranol)

Figure 5 Decomposition of atranorin and chloroatranorin during oak moss processing.

\footnotetext{
${ }^{31}$ Bouges, H.; Monchot, A.; Antoniotti, S. Enzyme-Catalysed Conversion of Atranol and Derivatives into Dimeric Hydrosoluble Materials: Application to the Preparation of a Low-Atranol Oakmoss Absolute. Cosmetics 2018, 5. https://doi.org/10.3390/cosmetics5040069.

32 Mowitz, M.; Zimerson, E.; Svedman, C.; Bruze, M. Patch Testing with Serial Dilutions and Thin-Layer Chromatograms of Oak Moss Absolutes Containing High and Low Levels of Atranol and Chloroatranol. Contact Dermatitis 2013, 69, 342-349. https://doi.org/10.1111/cod.12126.

33 Johansen, J. D.; Bernard, G.; Giménez-Arnau, E.; Lepoittevin, J. P.; Bruze, M.; Andersen, K. E. Comparison of Elicitation Potential of Chloroatranol and Atranol - 2 Allergens in Oak Moss Absolute. Contact Dermatitis 2006, 54, 192-195. https://doi.org/10.1111/j.0105-1873.2006.00814.x.
} 
Contact dermatitis induced by allergenic fragrances present in cosmetic products is a widely recognized problem. Its study is considered essential to avoid public health problems.

Allergenic fragrances can be added to cosmetic products directly or as components of essential oils or natural extracts; they can also appear as impurities of other cosmetic ingredients.

Currently, in the European Union it is mandatory to inform consumers of the presence in cosmetic products of any of the substances labelled as allergenic fragrances, if they are present above a certain level, and there are also restrictions on the maximum level allowed for some of them. ${ }^{34,35}$

The Scientific Committee on Consumer Safety (SCCP) concluded in $2004^{36}$ that atranol and chloroatranol, the main allergenic constituents of oakmoss and tree moss extracts, should not be present in consumer products because they were very potent allergens. ${ }^{37}$ These substances have been the cause of the largest proportion of the cases of contact allergies to cosmetic products in recent years, so their use in cosmetic products was banned in $2017 .{ }^{38}$ These two compounds were added to Annex II to Regulation (EC) No. 1223/2009 of the European Parliament and the Cosmetic Products Council. As of 23

\footnotetext{
${ }^{34}$ Uter, W.; Johansen, J. D.; Börje, A.; Karlberg, A. T.; Lidén, C.; Rastogi, S.; Roberts, D.; White, I. R. Categorization of Fragrance Contact Allergens for Prioritization of Preventive Measures: Clinical and Experimental Data and Consideration of Structure-Activity Relationships. Contact Dermatitis 2013, 69, 196-230. https://doi.org/10.1111/cod.12117.

35 EC 2003, Directive 2003/15/EC of the European Parliament and of the Council of 27 February 2003 Amending Council Directive 76/768/EEC on the Approximation of the Laws of the Member States Relating to Cosmetic Products, L66/26, 2003.

${ }^{36}$ SCCP. Opinion on Atranol and Chloroatranol present in natural extracts (e.g. oakmoss and tree moss extract). Scientific Committee on Consumer Products, adopted 7 December 2004. 2004

${ }^{37}$ a) Bernard, G.; Giménez-Arnau, E.; Rastogi, S. C.; Heydorn, S.; Johansen, J. D.; Menné, T.; Goossens, A.; Andersen, K.; Lepoittevin, J. P. Contact Allergy to Oak Moss: Search for Sensitizing Molecules Using Combined BioassayGuided Chemical Fractionation, GC-MS, and Structure-Activity Relationship Analysis. Arch. Dermatol. Res. 2003, 295, 229-235. https://doi.org/10.1007/s00403-003-0426-3. b) Johansen, J. D.; Andersen, K. E.; Svedman, C.; Bruze, M.; Bernard, G.; Gimenez-Arnau, E.; Rastogi, S. C.; Lepoittevin, J. P.; Menné, T. Chloroatranol, an Extremely Potent Allergen Hidden in Perfumes: A Dose-Response Elicitation Study. Contact Dermatitis 2003, 49, 180-184. https://doi.org/10.1111/j.0105-1873.2003.0214.x.

38 REGULATION (EU) 2017/1410. Accessible at https://eur-lex.europa.eu/legalcontent/GA/TXT/?uri=CELEX:32017R1410. Accessed October 20, 2020.
} 
August 2019, cosmetic products containing these substances should not be placed on the market. ${ }^{31}$

However, cosmetic product regulations do not regulate the oakmoss extract levels, and neither the levels of atranol and chloroatranol in the extract, in cosmetic products, and removing these substances from a complex blend of natural origin, such as absolute oakmoss, is very complicated. , $31,32^{2}$

\section{Methods for the analysis of allergenic fragances}

There are 24 allergenic fragrances that are volatile enough to be analyzed by GC in leaveon products ${ }^{39}$, these products can be injected directly without an additional sample preparation step. Detection is performed by MS (method EN 16274:2012). However, complex matrices, such as oakmoss and tree moss extracts, cannot be analyzed directly by GC-MS because they contain non-volatile compounds, which can result in contamination and deterioration of the chromatographic columns used. ${ }^{40}$

The content of atranol and chloroatranol in cosmetic products depends on the oakmoss or tree moss extracts used, on the degree of degradation of atranorin and chloroatranorin in the extract and, finally, on the matrix effect on the determination of these substances. ${ }^{41}$

The number of publications dealing with the determination of these two natural moss extracts is quite limited. Atranol and chloroatranol can be analyzed using LC-MS-MS. ${ }^{42}$ However, due to the high complexity and low volatility of the moss extract constituents, liquid chromatography with DAD detection is often preferred.

\footnotetext{
39 "Leave-on" cosmetic products are those that are not removed by rinsing after being applied to the skin, hair, mucous membranes, etc. Cosmetic products that are removed by rinsing after application (such as shampoos, soaps, hair conditioners, etc.) are called "rinse-off".

${ }^{40}$ Desmedt, B.; Canfyn, M.; Pype, M.; Baudewyns, S.; Hanot, V.; Courselle, P.; De Beer, J. O.; Rogiers, V.; De Paepe, K.; Deconinck, E. HS-GC-MS Method for the Analysis of Fragrance Allergens in Complex Cosmetic Matrices. Talanta 2015, 131, 444-451. https://doi.org/10.1016/j.talanta.2014.08.006.

41 Nardelli, A.; Giménez-Arnau, E.; Bernard, G.; Lepoittevin, J. P.; Goossens, A. Is a Low Content in Atranol/Chloroatranol Safe in Oak Moss-Sensitized Individuals? Contact Dermatitis 2009, 60, 91-95. https://doi.org/10.1111/j.1600-0536.2008.01478.x.

${ }^{42}$ Rastogi, S. C.; Bossi, R.; Johansen, J. D.; Menné, T.; Bernard, G.; Giménez-Arnau, E.; Lepoittevin, J. P. Content of Oak Moss Allergens Atranol and Chloroatranol in Perfumes and Similar Products. Contact Dermatitis 2004, 50, $367-$ 370. https://doi.org/10.1111/j.0105-1873.2004.00379.x.
} 
In 2004, Bossi and coworkers quantified the two atranol allergens in perfumes using negative MS-ESI, ${ }^{43}$ and Rastogi and coworkers published analyses of atranol and chloroatranol, using LC-ESI-MS-MS. ${ }^{42}$ The Goursot group has described two analytical methods for quantifying atranol and chloroatranol in moss extracts using LC with two different detection modes, DAD and ESI-MS. ${ }^{44}$ Finally, Boeye's group used HPLC with an electrochemical detector to analyze these compounds. ${ }^{45}$

A recurring problem with these methods is the low recovery $(40-50 \%)$ of atranol in perfume analysis.

\subsection{Phthalates}

Phthalates, or diesters of phthalic acid, have been used since the 1920s as additives in the manufacture of organic polymers. These compounds are mainly used as primary plasticizers, mainly in PVC or soft plastics, to increase their flexibility and longevity. They are also used, with other functions, in personal care and consumer products in general. ${ }^{46,47,48,49}$

\footnotetext{
${ }^{43}$ Bossi, R.; Rastogi, S. C.; Bernard, G.; Gimenez-Arnau, E.; Johansen, J. D.; Lepoittevin, J. P.; Menné, T. A Liquid Chromatography-Mass Spectrometric Method for the Determination of Oak Moss Allergens Atranol and Chloroatranol in Perfumes. J. Sep. Sci. 2004, 27, 537-540. https://doi.org/10.1002/jssc.200301696.

${ }^{44}$ Goursot, J. F. A Collaborative Work on Quantitative HPLC Methods for the Routine Determination of Atranol and Chloroatranol in Moss Extracts. Flavour Fragr. J. 2019, 34, 28-35. https://doi.org/10.1002/ffj.3475.

${ }^{45}$ Boeye, G.; Gismera, M. J.; Sevilla, M. T.; Procopio, J. R. Selective Method Based on Electrochemical Detection Coupled HPLC for Determination of the Allergens Atranol and Chloroatranol. Electroanalysis 2017, 29, 116-122. https://doi.org/10.1002/elan.201600479.

${ }^{46}$ Ribeiro, C.; Mendes, V.; Peleteiro, B.; Delgado, I.; Araújo, J.; Aggerbeck, M.; Annesi-Maesano, I.; Sarigiannis, D.; Ramos, E. Association between the Exposure to Phthalates and Adiposity: A Meta-Analysis in Children and Adults. Environ. Res. 2019, 179108780 https://doi.org/10.1016/j.envres.2019.108780.

${ }^{47}$ Li, F.; Liu, Y.; Wang, D.; Zhang, C.; Yang, Z.; Lu, S.; Wang, Y. Biodegradation of Di-(2-Ethylhexyl) Phthalate by a Halotolerant Consortium LF. PLoS One 2018, 13, 1-13. https://doi.org/10.1371/journal.pone.0204324.

${ }^{48}$ Dargnat, C.; Teil, M. J.; Chevreuil, M.; Blanchard, M. Phthalate Removal throughout Wastewater Treatment Plant. Case Study of Marne Aval Station (France). Sci. Total Environ. 2009, 407, 1235-1244. https://doi.org/10.1016/j.scitotenv.2008.10.027.

49 Hauser, R.; Calafat, A. M. Phthalates and Human Health. Occup. Environ. Med. 2005, 62, 806-818. https://doi.org/10.1136/oem.2004.017590.
} 
In the cosmetic industry, phthalates have been used in perfumes as carriers or synthetic musk solvents, for their fixing properties. They have also been used as plasticizers in nail lacquers and hair sprays. ${ }^{27,28,50}$

These substances do not chemically bind to the materials to which they are added, so they display great mobility. Consequently, they are widely distributed in the environment (soil, air, sediments and wastewater sludge). ${ }^{47}$ Most of them have low volatility, except for those with shorter alkyl chains, mainly DMP and diethyl phthalate (DEP), which makes them persistent pollutants. ${ }^{49}$

The compounds in this family are generally considered to be endocrine disruptors (EDCs). Exposure to endocrine disruptors is one of the factors contributing to the increased rate of certain health problems, such as obesity. ${ }^{46,51}$

The main systems and organs affected by contact with EDCs are bone growth, the immune system, the cardiovascular system, the digestive system, the reproductive system, the kidney and the liver. ${ }^{52}$

Phthalates and their metabolites have been detected in various human and animal fluids, including breast milk, seminal fluids and urine. ${ }^{53}$

Due to their harmful properties, coupled with their negative environmental impact, European legislation currently restricts the presence of phthalates in many consumer products. ${ }^{48}$ The substances listed in Figure 6 are regulated in cosmetic products in the European Union by Regulation 1223/2009.

\footnotetext{
50 Chen, H.; Wang, C.; Wang, X.; Hao, N.; Liu, J. Determination of Phthalate Esters in Cosmetics by Gas Chromatography with Flame Ionization Detection and Mass Spectrometric Detection. Int. J. Cosmet. Sci. 2005, 27 , 205-210. https://doi.org/10.1111/j.1467-2494.2005.00249.x.

${ }^{51}$ Meeker, J. D.; Sathyanarayana, S.; Swan, S. H. Phthalates and Other Additives in Plastics: Human Exposure and Associated Health Outcomes. Philos. Trans. R. Soc. B Biol. Sci. 2009, 364, 2097-2113. https://doi.org/10.1098/rstb.2008.0268.

${ }^{52}$ Seibert, D.; Quesada, H.; Bergamasco, R.; Borba, F. H.; Pellenz, L. Presence of Endocrine Disrupting Chemicals in Sanitary Landfill Leachate, Its Treatment and Degradation by Fenton Based Processes: A Review. Process Saf. Environ. Prot. 2019, 131, 255-267. https://doi.org/10.1016/j.psep.2019.09.022.

${ }^{53}$ Li, B.; Xu, X.; Zhu, Y.; Cao, J.; Zhang, Y.; Huo, X. Neonatal Phthalate Ester Exposure Induced Placental MTs, FATP1 and HFABP MRNA Expression in Two Districts of Southeast China. Sci. Rep. 2016, 6, 1-7. https://doi.org/10.1038/srep21004.
} 
<smiles>CCCCOC(=O)c1ccccc1C(=O)OCc1ccccc1</smiles>

Benzyl butyl phthalate (BBP)

CAS 85-68-7<smiles>CC(C)CCOC(=O)c1ccccc1C(=O)OCCC(C)C</smiles>

\section{Diisopentyl phthalate} (DiPP) CAS 605-50-5<smiles>CCCCOC(=O)c1ccccc1C(=O)OCCCC</smiles>

Dibutyl phthalate (DBP) CAS 84-74-2<smiles>COCCOC(=O)c1ccccc1C(=O)OCCOC</smiles>

Dimethoxyethyl phthalate (DMEP) CAS 117-82-8<smiles>CCCCC(CC)COC(=O)c1ccccc1C(=O)OCC(CC)(CC)CCCC</smiles>

Diethylhexyl phthalate (DEHP) CAS 117-81-7<smiles>CCCCCOC(=O)c1ccccc1C(=O)OCCCCC</smiles>

\section{Dipentyl phthalate (DnPP) \\ CAS 131-18-0}<smiles>CCCCCOC(=O)c1ccccc1C(=O)OCCC(C)C</smiles><smiles>CC(C)COC(=O)c1ccccc1C(=O)OCC(C)C</smiles>

Figure 6 Phthalates restricted by Regulation 1223/2009 of the European Union

\section{Di-n-octylphthalalate}

Although DMP and DEP are the main phthalates used in cosmetics, their use is not banned in Europe. Nevertheless, they are listed as pollutants and are controlled by the EPA (U.S. Environmental Protection Agency). ${ }^{27}$ DNOP (di-n-octylphthalate) is in the same situation, being widely detected in wastewater. ${ }^{54}$

\footnotetext{
${ }^{54}$ Chowdhary, P.; Raj, A.; Bharagava, R. N. Environmental Pollution and Health Hazards from Distillery Wastewater and Treatment Approaches to Combat the Environmental Threats: A Review. Chemosphere 2018, 194, $229-246$. https://doi.org/10.1016/j.chemosphere.2017.11.163.
} 
<smiles>COC(=O)c1ccccc1C(=O)OC</smiles>

Dimethylphthalate (DMP)

CAS 131-11-3<smiles>CCOC(=O)c1ccccc1C(=O)OCC</smiles>

Diethylphthalate

(DEP)

CAS 84-66-2<smiles>CCOC(=O)c1ccccc1C(=O)OCC</smiles>

\section{Di-n-octylphthalate \\ (DnOP) \\ CAS 117-84-0}

Figure 7 EPA-controlled phthalates

\section{Methods for phthalates analysis}

LC-UV analysis for phthalates is a fast and sensitive enough methodology to be used in the determination of these substances in cosmetics. Alternatively, they can be analyzed by GC-FID, GC-MS or GC-MS/MS. ${ }^{27,28,29,55}$ In the case of non-polar, semi-volatile and thermostable compounds, the method of choice for their analysis in various matrices is usually GC-MS. ${ }^{56,57,58}$

The EN 16521:2014 method allows the analysis of 12 different phthalates in cosmetic product samples, directly or after prior dilution in ethanol. Analytes are separated in a chromatographic column (GC), using a temperature gradient, and detection is carried out with an electronic impact (EI) detector.

\footnotetext{
${ }^{55}$ López-Nogueroles, M.; Benedé, J. L.; Chisvert, A.; Salvador, A. A Rapid and Sensitive Gas Chromatography-Mass Spectrometry Method for the Quality Control of Perfumes: Simultaneous Determination of Phthalates. Analytical Methods 2013, 5, 409-415. https://doi.org/10.1039/C2AY26130H.

${ }^{56}$ Shen, H. Y.; Jiang, H. L.; Mao, H. L.; Pan, G.; Zhou, L.; Cao, Y. F. Simultaneous Determination of Seven Phthalates and Four Parabens in Cosmetic Products Using HPLC-DAD and GC-MS Methods. J. Sep. Sci. 2007, 30, 48-54. https://doi.org/10.1002/jssc.200600215.

${ }^{57}$ Gimeno, P.; Maggio, A. F.; Bousquet, C.; Quoirez, A.; Civade, C.; Bonnet, P. A. Analytical Method for the Identification and Assay of 12 Phthalates in Cosmetic Products: Application of the ISO 12787 International Standard "Cosmetics-Analytical Methods-Validation Criteria for Analytical Results Using Chromatographic Techniques." J. Chromatogr. A 2012, 1253, 144-153. https://doi.org/10.1016/j.chroma.2012.06.090.

58 Kaur, R.; Heena; Kaur, R.; Rani, S.; Malik, A. K. Simple and Rapid Determination of Phthalates Using Microextraction by Packed Sorbent and Gas Chromatography with Mass Spectrometry Quantification in Cold Drink and Cosmetic Samples. J. Sep. Sci. 2016, 39, 923-931. https://doi.org/10.1002/jssc.201500642.
} 


\subsection{Analytical control of cosmetic products}

Given the regulatory restrictions mentioned above, and in order to ensure the compliance of cosmetic products with existing regulations before putting them on the market, they must be analyzed in accredited analytical laboratories. Therefore, analytical methods capable of detecting the presence of traces of prohibited and/or quantifying restricted ingredients in raw materials and finished products are required.

The composition of cosmetic products is generally complex, including many different types of ingredients that need to be controlled. Many of the substances present in the commercial products can interfere with the characterization and quantification of the analytes of interest. This creates the need for a continuous development of improved analytical methods to carry out a rigorous quality control of regulated and/or prohibited ingredients in cosmetics.

In contrast to this need for control, deficiencies have been observed in certain areas of the analysis of cosmetic products (i.e. detection of musks or phthalates), and there is a need for the development of improved analytical methodologies. On the other hand, certain natural extracts of lichens, considered as allergens, present a very complex composition and cannot be easily identified with the usual analytical methods. ${ }^{59}$

Cosmetic products are highly complex, both in their diversity and their composition. Therefore, the analytical methods developed to ensure their safety must be simple, reliable, and transferable. ${ }^{60}$

In order to approach the development of reliable analytical methods, it is essential to have access to standards of all the substances to be analyzed in order to perform identification and to use internal standards to perform quantification. However, in addition to having these standards available, surrogate standards are also tipically used to evaluate the efficiency of the sample treatment steps (the recovery of the substance to be isolated and quantified). These surrogate standards are compounds structurally similar to the analytes to be isolated and quantified, which are added to the samples to be analyzed in known

\footnotetext{
${ }^{59}$ Analysis of Cosmetic Products, Second Ed., Salvador, A.; Chisvert, A., Eds. Elsevier 2017.

${ }^{60}$ Weston, C.; Smuts, J.; Mao, J. X.; Schug, K. A. Investigation of Gas Phase Absorption Spectral Similarity for StableIsotopically Labeled Compounds in the 125-240 Nm Wavelength Range. Talanta 2018, 177, 41-46. https://doi.org/10.1016/j.talanta.2017.09.033.
} 
quantities, and whose recovery when applying the corresponding analytical method is easily determined. ${ }^{61}$

The synthesis of suitable surrogate compounds is deemed necessary to improve and develop analytical methods for the control of cosmetic products. They are neccesary to determine whether these analytical methods are efficient, quantitative and reproducible. The most suitable surrogates are isotopically labeled analogs of the analytes of interest. Unfortunately, it is very rare that these kinds of isotopically labeled surrogates are readily available.

One way to increase the precision and accuracy of mass spectrometry determinations, one of the benchmark analytical techniques in cosmetic analysis, is to use stable and isotopically-labeled internal standards, which perfectly mimic their unlabeled analogues. 60 The mass peaks originated by the deuterated compounds, in particular, are easy to distinguish when using mass detection, since isotopic substitution increases the molecular mass of the ions of interest in a totally predictable way. ${ }^{62,63,64}$

When these labeled standards are added to the sample of interest, and are incorporated through the entire validation, determination, and calibration process, peaks from internal standards are often used to normalize those of the target analyte, thus reducing systematic errors and method randoms. Similarly, the use of these compounds has advantages in the study of samples that suffer severe matrix effects.

The incorporation of deuterium $\left(\mathrm{D},{ }^{2} \mathrm{H}\right)$ at specific positions of the structure of a molecule is frequently used to access isotopically-labeled compounds of medium molecular mass,

\footnotetext{
${ }^{61}$ a) Penner, N.; Ramanathan, R.; Zgoda Pols, J.; Chowdhury, S. Quantitative Determination of Hippuric and Benzoic Acids in Urine by LC-MS/MS Using Surrogate Standards. J. Pharm. Biomed. Anal. 2010, 52 (4), $534-543$. https://doi.org/10.1016/j.jpba.2010.01.016; b) Clifford, M. N.; Madala, N. E. Surrogate Standards: A Cost-Effective Strategy for Identification of Phytochemicals. J. Agric. Food Chem. 2017, 65 (18), 3589-3590. https://doi.org/10.1021/acs.jafc.7b01588; c) Dagnon, S.; Novkova, Z.; Bojilov, D.; Nedialkov, P.; Kouassi, C. Development of Surrogate Standards Approach for the Determination of Polyphenols in Vernonia Amygdalina Del. J. Food Compos. Anal. 2019, 82, 103231. https://doi.org/10.1016/j.jfca.2019.06.003.

${ }^{62}$ Vogl, J.; Rosner, M.; Pritzkow, W. The Need for New Isotope Reference Materials. Anal. Bioanal. Chem. 2013, 405, 2763-2770. https://doi.org/10.1007/s00216-012-6605-3.

63 Jennings, M.; Matthews, D. Determination of Complex Isotopomer Patterns in Isotopically Labeled Compounds by Mass Spectrometry. Anal. Chem. 2005, 77, 6435-6444. https://doi.org/10.1021/ac0509354

${ }^{64}$ Loh, Y. Y.; Nagao, K.; Hoover, A. J.; Hesk, D.; Rivera, N. R.; Colletti, S. L.; Davies, I. W.; Macmillan, D. W. C. Photoredox-Catalyzed Deuteration and Tritiation of Pharmaceutical Compounds. Science 2017, 358, 1182-1187. https://doi.org/10.1126/science.aap9674.
} 
since it is an inexpensive isotope, compared to ${ }^{13} \mathrm{C}$ or ${ }^{15} \mathrm{~N}$ and, additionally iy is not radioactive (unlike ${ }^{14} \mathrm{C}$ ). ${ }^{65}$

Deuterated compounds are of significant importance in organic synthesis, in mechanistic investigations, in mass spectrometric studies, and in pharmaceutical applications. ${ }^{66}$ However, although there are many commercially available deuterated compounds with a high degree of purity and level of isotopic labeling, including some that could be used as surrogate standards for common cosmetic products relevant analytes, they tend to be very expensive and most are unavailable. ${ }^{60,67}$ Accordingly, simple and inexpensive preparative methods are necessary and inexpensive to generalize their use.

In view of this limitation, we have undertaken in this work the development of synthetic procedures for the preparation of deuterated derivatives of the representative compounds of interest related to the analysis of cosmetic products: atranol, chloroatranol, di-n-octyl phthalate, and the musks xylene and ambrette. The preparation of these isotopically labelled substances has been achieved by using a variety of reactions to introduce deuterium atoms in organic molecules. These reactions include electrophilic aromatic substitutions, etherification of phenols, esterification of carboxylic acids, and selective reduction of esters to aldehydes. The methods developed herein open the way to prepare isotopically labelled surrogate standards of other analytes of interest.

\section{Results}

\section{Preparation of di-n-octyl phthalate-d4}

The proposed preparation method for di-n-octyl phthalate-d4 involves the esterification of tetradeuterated phthalic acid with n-octanol, as shown in Figure 8. In principle this method could be easily extenedel for the preparation of other primary phtalate esters.

\footnotetext{
65 Elmore, C. S. The Use of Isotopically Labeled Compounds in Drug Discovery; Elsevier, 2009; Vol. 44. https://doi.org/10.1016/S0065-7743(09)04425-X.

${ }^{66}$ Zhang, M.; Yuan, X. A.; Zhu, C.; Xie, J. Deoxygenative Deuteration of Carboxylic Acids with D2O. Angew. Chemie - Int. Ed. 2019, 58, 312-316. https://doi.org/10.1002/anie.201811522.

${ }^{67}$ Zhou, R.; Li, J.; Cheo, H. W.; Chua, R.; Zhan, G.; Hou, Z.; Wu, J. Visible-Light-Mediated Deuteration of Silanes with Deuterium Oxide. Chem. Sci. 2019, 10, 7340-7344. https://doi.org/10.1039/c9sc02818h.
} 
Our study began with the optimization of the unlabelled phthalic acid esterification reaction. The reaction was carried out under reflux in toluene in the presence of an acidic catalyst with 4.5 equivalents of n-octanol used. In this way the unlabelled di-n-octyl phthalate was obtained in a very good yield. Using these optimized conditions of esterification (entry 2 of the previous table) and starting from phthalic acid- $d 4$, the desired phthalate (69) was obtained, as a transparent oil with a moderate yield and maintaining a high percentage of deuteration ( $>98 \%$ ) (Figure 8$)$.<smiles>[2H]c1c([2H])c([2H])c(C(=O)O)c(C(=O)O)c1[2H]</smiles>

1

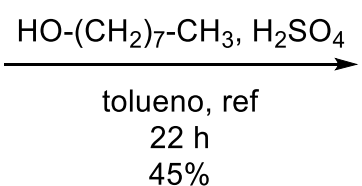

$45 \%$<smiles>[2H]c1c([2H])c([2H])c(C(=O)OCCCCCCCC)c(C(=O)OCCCCCCCC)c1[2H]</smiles>

2

Figure 8 Reaction for the preparation of di-n-octyl phthalate-d4

In the ${ }^{1} \mathrm{H}-\mathrm{NMR}$ spectrum of tetradeuterated phthalate $\mathbf{1}$, the following signals can be highlighted: a triplet at $\delta 4.29 \mathrm{ppm}(\mathrm{J}=6.7 \mathrm{~Hz}, 4 \mathrm{H})$, a doublet of quartets at $\delta 1.74 \mathrm{ppm}$ $(\mathrm{J}=8.3,6.7 \mathrm{~Hz}, 4 \mathrm{H})$ and a multiplet at $\delta 1.48-1.26 \mathrm{ppm}(\mathrm{m}, 20 \mathrm{H})$, corresponding to the protons of the alkyl chain, as well as a multiplet at $\delta 0.95-0.87 \mathrm{ppm}$, corresponding to the methyl groups of the molecule. In the ${ }^{13} \mathrm{C}-\mathrm{NMR}$ spectrum, the most diagnostic signals were found at $\delta 167.8 \mathrm{ppm}$, corresponding to the carboxyl of the ester group; between $\delta$ 127.9 and $132.0 \mathrm{ppm}$, corresponding to the aromatic carbons, between $\delta 22.3$ and 65.5 ppm, corresponding to the carbons of the alkyl chain, and a signal at $\delta 13.0 \mathrm{ppm}$, corresponding to the two methyl groups.

\section{Preparation of musk ambrette-d3}

The preparation of the trideuterated derivative of musk ambrette was approached through a two-step procedure (Figure 9).

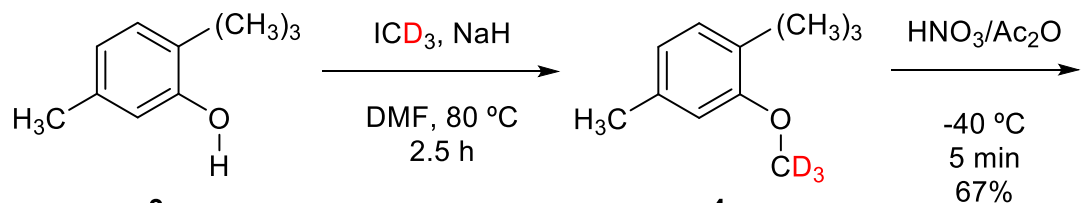

3
4<smiles>Cc1cc([N+](=O)[O-])c(C)c([N+](=O)[O-])c1OC(=O)O</smiles>

5

Figure 9 Preparation of musk ambrette-d3 
The first stage consisted of the alkylation of 2-(tert-butyl)-5-methylphenol with trideuterated methyl iodide, which afforded the trideuterated ether $\mathbf{4}$ as a clear oil. The most characteristic signals of the $1 \mathrm{H}-\mathrm{NMR}$ spectrum of this product are two singlets at $\delta$ $1.31 \mathrm{ppm}(9 \mathrm{H})$ and $2.26 \mathrm{ppm}(3 \mathrm{H}) \mathrm{ppm}$, corresponding to the twelve methyl protons, and two signals at $\delta 6.65$ and $7.05 \mathrm{ppm}$, corresponding to the three aromatic protons.

For the second step, a double nitration of the trideuteromethyl ether $\mathbf{4}$, an optimization of the nitration conditions was initially carried out with the unlabelled substrate, assaying different nitrating mixtures and reaction temperatures. The conditions tested and the results obtained are shown in the following table:

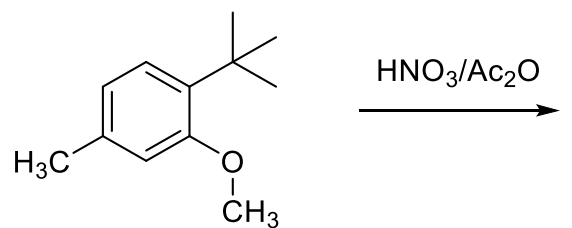

3<smiles>COc1c(C(C)(C)C)cc([N+](=O)[O-])c(C)c1[N+](=O)[O-]</smiles>

3a<smiles>COc1ccc([N+](=O)[O-])c(C)c1[N+](=O)[O-]</smiles>

$3 b$

\begin{tabular}{|c|c|c|c|c|c|}
\hline Entry & Reactives & $\mathbf{T}$ & $\mathbf{t}$ & Result & Yield 3a \\
\hline $\mathbf{1}$ & $\mathrm{HNO}_{3}(24$ eq. $) / \mathrm{H}_{2} \mathrm{SO}_{4}(21$ eq. $)$ & $0{ }^{\circ} \mathrm{C}$ & $4 \mathrm{~h}$ & $\mathbf{3 b}$ & \\
\hline $\mathbf{2}$ & $\mathrm{HNO}_{3}(2.1$ eq. $) / \mathrm{MeOH}$ & ta & $12 \mathrm{~h}$ & Complex mix & \\
\hline $\mathbf{3}$ & $\mathrm{HNO}_{3}(1.2$ eq. $) / \mathrm{Ac}_{2} \mathrm{O}(1.6$ eq. $)$ & $0^{\circ} \mathrm{C}$ & $15 \mathrm{~min}$ & Complex mix & \\
\hline $\mathbf{4}$ & $\mathrm{Cu}\left(\mathrm{NO}_{3}\right)_{2}$ & $90^{\circ} \mathrm{C}$ & $20 \mathrm{~min}$ & Mix of 3a and $\mathbf{3 b}$ & \\
\hline $\mathbf{5}$ & $\mathrm{Cu}\left(\mathrm{NO}_{3}\right)_{2}$ & $90^{\circ} \mathrm{C}$ & $3 \mathrm{~h}$ & Complex mix & \\
\hline $\mathbf{7}$ & $\mathrm{HNO}_{3}(5$ eq. $) / \mathrm{Ac}_{2} \mathrm{O}(3$ eq. $)$ & $-10^{\circ} \mathrm{C}$ & $2.5 \mathrm{~min}$ & $\mathbf{3 a}$ & $60 \%$ \\
\hline $\mathbf{8}$ & $\mathrm{HNO}_{3}(5$ eq. $) / \mathrm{Ac}_{2} \mathrm{O}(3$ eq. $)$ & $-40^{\circ} \mathrm{C}$ & 5 min & $\mathbf{3 a}$ & $70 \%$ \\
\hline
\end{tabular}

Table 1 Optimization of the nitration reaction to obtain musk ambrette

For the optimization study, different nitration conditions described in the literature were tested, however, in most cases a complex mixture of products was obtained. One of the (unwanted) reaction products observed was nitro compound $\mathbf{3 b}$, which is the result of the double nitration of the starting ether followed by the loss of the tert-butyl group due to the drastic acidic reaction conditions that had to be employed. Finally, the desired musk ambrette could be prepared in good yield (70\%) by using $\mathrm{HNO}_{3} / \mathrm{Ac}_{2} \mathrm{O}$ as nitrating agent, at low temperature. 
Once the nitration conditions were optimized, the deuterated musk ambrette was prepared in good yield by using nitric acid and acetic anhydride as nitrating agent on compound $\mathbf{4}$, at low temperature (Figure 9).

The trideuterated musk ambrette was obtained as an oil, for which the characteristic signals of its ${ }^{1} \mathrm{H}-\mathrm{NMR}$ spectrum are two singlets at $\delta 1.43(9 \mathrm{H})$ and $\delta 2.37(3 \mathrm{H}) \mathrm{ppm}$, corresponding to the tert-butyl group and the methyl located between the two nitro groups, respectively, and another singlet $(1 \mathrm{H}) \delta 8.09 \mathrm{ppm}$, corresponding to the only aromatic proton in the molecule.

\section{Preparation of musk xylene-d9}

Musk xylene- $d 9$ musk was prepared in two steps. The first step was the Frieldel-Crafts alkylation of m-xylene with deuterated tert-butyl chloride, catalyzed by a rhenium complex. This provided the desired intermediate- $d 97$, as a clear oil (Figure 10). Then, a triple nitration of the intermediate 7 by treatment with a nitrating mixture of nitric acid and sulfuric acid was carried out. This reaction resulted in the formation of the desired xylene- $d 9$ musk as a white solid, albeit in moderate yield.

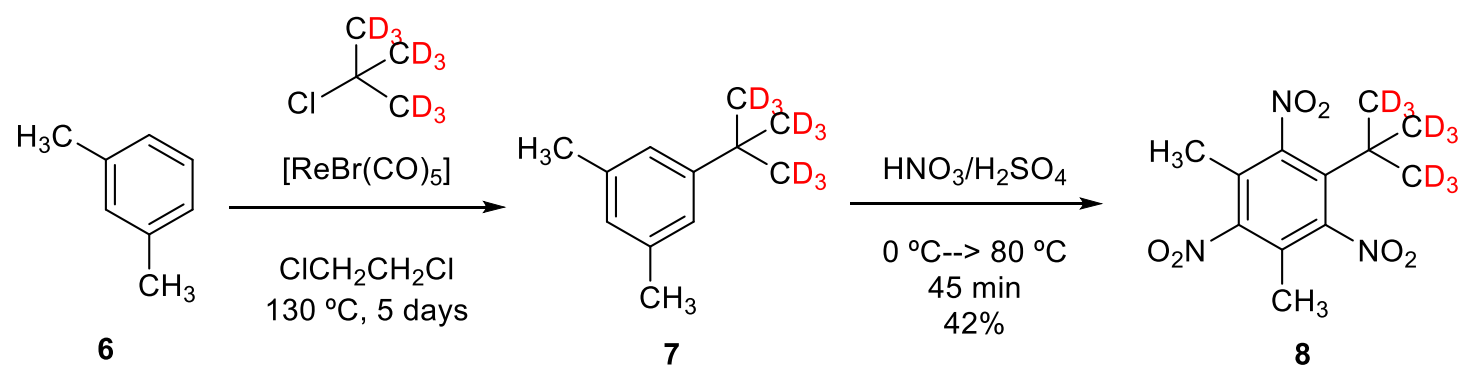

Figure 10 Sequence of reactions for the preparation of nonadeuterated musk xylene

Nonadeuterated musk xylene is obtained as a whitish crystalline solid, with a characteristic signal at $\delta 2.16 \mathrm{ppm}(3 \mathrm{H})$ being observed in its ${ }^{1} \mathrm{H}-\mathrm{NMR}$ spectrum, corresponding to the only non-deuterated methyl group of the molecule. In the ${ }^{13} \mathrm{C}-\mathrm{NMR}$ spectrum, signals can be observed between $\delta 150.3$ and $124.4 \mathrm{ppm}$, corresponding to the aromatic carbons, and at $\delta 12.0 \mathrm{ppm}$, corresponding to the methyl group.

\section{Preparation of atranol-d}

The isotopically labeled atranol (11) was synthesized in two steps, starting from 2,6dihydroxy-4-methylbenzoic acid (9). The first step was a protection reaction, at low 
temperature, of the carboxylic group and one of the phenols in the ortho position to it, using acetone in the presence of trifluoroacetic anhydride and trifluoroacetic acid as a catalyst. 5-Hydroxy-2,2,7-trimethyl-4H-1,3-benzodioxin-4-one (10) was obtained as a pale yellow solid. In a second step, acetonide $\mathbf{1 0}$ was reduced with a solution of DIBAL$\mathrm{D}$ in dry dichloromethane (slow addition over 4 hours) at low temperature. After corresponding purification, the desired deuterated product was obtained as a yellow solid, although in low yield (Figure 11).<smiles>Cc1cc(O)c(C(=O)O)c(O)c1</smiles>

9<smiles>Cc1cc(O)c2c(c1)OC(C)(C)OC2=O</smiles>

10

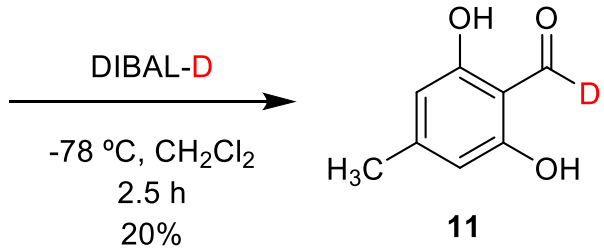

$20 \%$

Figure 11 Sequence of reactions for the preparation of deuterated atranol

The atranol- $d$ compound presents as characteristic signals in its ${ }^{1} \mathrm{H}-\mathrm{NMR}$ spectrum a singlet at $\delta 2.23 \mathrm{ppm}(3 \mathrm{H})$ corresponding to the methyl group and another singlet at $\delta$ $6.16 \mathrm{ppm}(2 \mathrm{H})$, corresponding to the 2 aromatic protons. In the ${ }^{13} \mathrm{C}-\mathrm{NMR}$ spectrum of the product, signals appear at $\delta 21.0\left(\mathrm{CH}_{3}\right)$, between $\delta 106.9$ and $162.3 \mathrm{ppm}$ (aromatic $\mathrm{C}$ ) and at 193.1 ppm (aldehyde C).

\section{Preparation of chloroatranol-d}

Our approach to the synthesis of chloroatranol-d was based on the monochlorination of an unprotected, adequately substituted benzoic acid with sulfuryl chloride. The following table lists the conditions used in the reaction optimization study carried out.<smiles>Cc1cc(O)c(C(=O)O)c(O)c1</smiles>

9

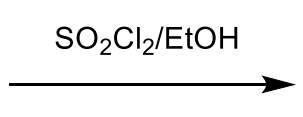<smiles>Cc1c(Cl)c(O)c(C(=O)O)c(O)c1Cl</smiles>

$12 b$

\begin{tabular}{|c|c|c|c|c|c|c|c|}
\hline Entry & Solvent & $\mathbf{S O}_{2} \mathbf{C l}_{2}$ & $\mathbf{E t O H}$ & $\mathbf{T}$ & $\mathbf{t}$ & Conc. & Products \\
\hline $\mathbf{1}$ & Chloroform & $1.05 \mathrm{eq}$ & $3 \mathrm{~mL}$ & ta & $3.5 \mathrm{~h}$ & $0.09 \mathrm{M}$ & $\begin{array}{c}\mathbf{1 2 a}+\mathbf{1 2 b} \\
(3: 8)\end{array}$ \\
\hline $\mathbf{2}$ & Chloroform & $0.51 \mathrm{eq}$ & $2.95 \mathrm{~mL}$ & ta & $1 \mathrm{~h}$ & $0.09 \mathrm{M}$ & $\begin{array}{c}\mathbf{1 2 a}+\mathbf{1 2 b} \\
(1: 1)\end{array}$ \\
\hline $\mathbf{3}$ & Chloroform & $0.47 \mathrm{eq}$ & $2.72 \mathrm{~mL}$ & $-15^{\circ} \mathrm{C}$ & $1 \mathrm{~h}$ & $0.1 \mathrm{M}$ & $\begin{array}{c}\mathbf{1 2 a}+\mathbf{1 2 b} \\
(3: 1.3)\end{array}$ \\
\hline
\end{tabular}




\begin{tabular}{|c|c|c|c|c|c|c|c|}
\hline $\mathbf{4}$ & Chloroform & $0.5 \mathrm{eq}$ & $2.72 \mathrm{~mL}$ & $-15^{\circ} \mathrm{C}$ & $30 \mathrm{~min}$ & $0.09 \mathrm{M}$ & $\begin{array}{c}\mathbf{1 2 a}+12 b \\
(1: 1)\end{array}$ \\
\hline $\mathbf{5}$ & Ether & $0.5 \mathrm{eq}$ & & ta & $15 \mathrm{~min}$ & $0.16 \mathrm{M}$ & $\mathrm{SM}$ \\
\hline $\mathbf{6}$ & Ether & $1 \mathrm{eq}$ & $1.5 \mathrm{~mL}$ & ta & $1 \mathrm{~h}$ & & $\begin{array}{c}\mathrm{SM}+\mathbf{1 2 a} \\
(3: 1)\end{array}$ \\
\hline $\mathbf{7}$ & Ether & $1 \mathrm{eq}$ & $1.5 \mathrm{~mL}$ & ta & $5 \mathrm{~h}$ & & $\begin{array}{c}\mathrm{SM}+\mathbf{1 2 a} \\
(1: 3)\end{array}$ \\
\hline $\mathbf{8}$ & Ether & $1 \mathrm{eq}$ & $0.1 \mathrm{~mL}$ & ta & $7 \mathrm{~h}$ & & $\mathbf{1 2 a}$ \\
\hline
\end{tabular}

Table 1 Optimization of the chlorination reaction in the synthesis of chloroatranol

After optimization, it was possible to carry out the monochlorination of commercial 2,6dihydroxy-4-methylbenzoic acid in good yield, by using sulfuryl chloride in ether, for 7 hours at room temperature.

Subsequently, the monochlorinated product was subjected to protection (formation of the corresponding acetonide) and reduction with DIBAL-D, analogously to the process described for the case of atranol. The complete synthetic sequence is included in the following Figure. The final chloroatranol- $d$ was obtained as a greenish solid in $30 \%$ overall yield.<smiles>Cc1cc(O)c(C(=O)O)c(O)c1</smiles>

9

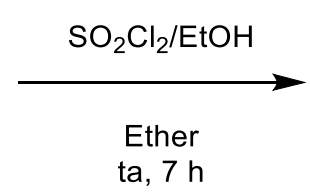

ta, $7 \mathrm{~h}$<smiles>Cc1cc(O)c(C(=O)O)c(O)c1Cl</smiles>

12

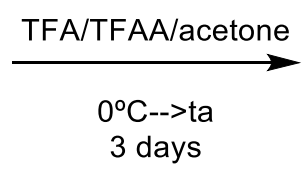

3 days<smiles>Cc1cc(O)c2c(c1Cl)OC(C)(C)OC2=O</smiles>

13

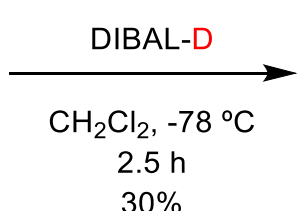

$30 \%$<smiles>[2H]C(=O)c1c(O)cc(C)c(Cl)c1O</smiles>

14

Figure 12 Sequence of reactions for the preparation of deuterated atranol

Monodeuterated chloroatranol $\mathbf{1 4}$ was obtained as a greenish solid, which showed two characteristic signals in ${ }^{1} \mathrm{H}-\mathrm{NMR}$ at $2.34\left(\mathrm{CH}_{3}\right)$ and 6.36 (aromatic proton) ppm. In the ${ }^{13} \mathrm{C}$-NMR spectrum of $\mathbf{1 4}$, signals can be observed at $19.9 \mathrm{ppm}$ (corresponding to the $\mathrm{C}$ 
of methyl), between 137.8 and 160.0 ppm corresponding to the aromatic Cs and at 193.2 ppm corresponding to the aldehyde carbonyl group.

\section{Conclusions}

We have established synthetic procedures to prepare and isotopically label different restricted substances that may be present in fragrances and cosmetic products, specifically musk xylene- $d 9$, musk ambrette- $d 3$, di-n-octyl phthalate- $d 4$, atranol- $d$ and chloroatranol$d$. These compounds, intended to be used as surrogate standards for the development and quality control of analysis of cosmetic articles, have been prepared through simple synthetic routes, and have been obtained with high deuteration levels (above 95\% of deuterium incorporation).

The synthetic methods used in this work to synthesize deuterated analogs of simple organic molecules should open the way for the preparation of a wide variety of isotopically labelled surrogate standards and the generalization of their use in the analysis of cosmetic and related products. 


\section{Experimental}

Preparation of di-n-octyl phthalate- $d 4$ (2)<smiles>[2H]c1c([2H])c([2H])c(C(=O)O)c(C(=O)O)c1[2H]</smiles>

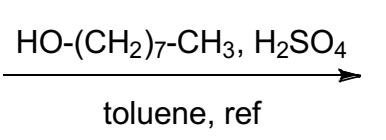<smiles>[2H]c1c([2H])c([2H])c(C(=O)OCCCCCCCCCCC)c(C(=O)OCCCCCC)c1[2H]</smiles>

2

Tetradeuterated phthalic acid ( $\left.0.15 \mathrm{~g}, 8.5 \times 10^{-4} \mathrm{~mol}, 1.0 \mathrm{eq}\right)(\mathbf{1}), \mathrm{n}$-octanol $(0.6 \mathrm{ml}, 3.7 \mathrm{x}$ $\left.10^{-3} \mathrm{~mol}, 4.5 \mathrm{eq}\right), 0.025 \mathrm{ml}$ of concentrated sulfuric acid and $15 \mathrm{ml}$ of toluene were added to a round-bottom flask provided with a magnetic stirring bar. The resulting mixture was heated to reflux (Dean-Stark apparatus, at $130^{\circ} \mathrm{C}$ ) overnight. The reaction mixture was then extracted with dichloromethane $(3 \times 20 \mathrm{ml})$ and the organic phase was washed with an aqueous solution of $\mathrm{NaOH}(3 \mathrm{M})(3 \times 20 \mathrm{ml})$ and water $(20 \mathrm{ml})$, then dried over anhydrous sodium sulfate, filtered and concentrated. The residue was purified by silica gel column chromatography $\left(\mathrm{CH}_{2} \mathrm{Cl}_{2}\right.$ :hex 1:1), affording $0.3 \mathrm{~g}(45 \%)$ of the desired product (2) as a clear oil.

${ }^{1} \mathrm{H}$ NMR (500 MHz, CD 3 OD) $\delta 4.29(\mathrm{t}, \mathrm{J}=6.7 \mathrm{~Hz}, 4 \mathrm{H}), 1.74(\mathrm{dq}, \mathrm{J}=8.3,6.7 \mathrm{~Hz}, 4 \mathrm{H})$, $1.48-1.26(\mathrm{~m}, 20 \mathrm{H}), 0.95-0.87(\mathrm{~m}, 6 \mathrm{H})$.

${ }^{13} \mathrm{C}$ NMR (126 MHz, CD 3 OD) $\delta$ 167.8, 132.0, 130.4 (t, J = 24.6 Hz, CD coupling), 128.1 (t, J = 24.9 Hz, CD coupling), 65.5, 31.5, 28.9, 28.9, 28.2, 25.7, 22.3, 13.0.

HRMS (ESI) calculated for $\mathrm{C}_{24} \mathrm{H}_{34} \mathrm{D}_{4} \mathrm{NaO}_{4}[\mathrm{M}+\mathrm{Na}]$ : 417.2913, found: 417.2911

Preparation of 6-tert-butyl-3-methyl-2,4-dinitro-anisole-d3 (musk ambrette-d3) (5)<smiles>Cc1ccc(C)c(O)c1</smiles>

3

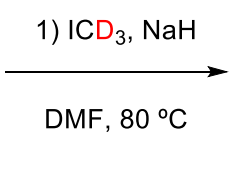

DMF, $80^{\circ} \mathrm{C}$

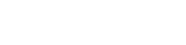

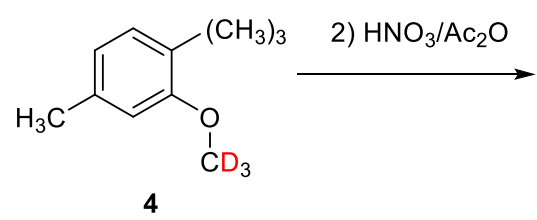

4<smiles>Cc1cc([N+](=O)[O-])c(C)c([N+](=O)[O-])c1OC(=O)O</smiles>

5

Step 1: A suspension of $\mathrm{NaH}(1.5 \mathrm{~g}, 0.058 \mathrm{~mol}, 10 \mathrm{eq})$ in mineral oil, $4 \mathrm{ml}$ of dry DMF and 2-(tert-butyl)-5-methylphenol $\left(0.95 \mathrm{~g}, 5.78 \times 10^{-3} \mathrm{~mol}\right)$ was prepared in a roundbottom flask fitted with a stirring bar, under argon atmosphere. The resulting mixture was 
stirred for $30 \mathrm{~min}$ at room temperature, after which trideuterated methyl iodide $(0.5 \mathrm{~mL}$, $7.92 \times 10^{-3} \mathrm{~mol}, 1.4 \mathrm{eq}$ ) was added. The resulting mixture was heated to $80{ }^{\circ} \mathrm{C}$. After 2 hours, it was allowed to cool to room temperature and the reaction was stopped by the addition of brine $(2 \mathrm{ml})$. The mixture was extracted with ethyl acetate $(3 \times 30 \mathrm{ml})$. The organic phase was dried over anhydrous sodium sulfate and concentrated. The residue was used directly in the next step without further purification.

Step 2: A mixture of nitric acid $\left(0.25 \mathrm{~mL}, 5.9 \times 10^{-3} \mathrm{~mol}, 5.4 \mathrm{eq}\right)$ and acetic anhydride $\left(0.2 \mathrm{ml}, 2.1 \times 10^{-3} \mathrm{~mol}, 3.29\right)$ was prepared in a round-bottom flask fitted with a stirring bar. The mixture was cooled to $-40^{\circ} \mathrm{C}$. Crude trideuteromethyl ether $\mathbf{4}$, obtained in the previous step $\left(0.2 \mathrm{ml}, 1.1 \times 10^{-3} \mathrm{~mol}, 1.0 \mathrm{eq}\right)$, dissolved in $0.2 \mathrm{ml}$ of acetic anhydride, was slowly added to this mixture. After $5 \mathrm{~min}$, the reaction was stopped by adding water/ice. The resulting solution was extracted with ether $(3 \times 30 \mathrm{ml})$. The organic phase was washed several times with a $5 \% \mathrm{NaOH}$ solution $(6 \times 2 \mathrm{ml})$, dried over anhydrous sodium sulfate and concentrated. The crude product was purified by silica gel column chromatography, eluting with 1:1 pentane/dichloromethane, affording $0.2 \mathrm{~g}$ of the desired compound $(67 \%)$, which was crystallized from ethanol. The deuteration percentage is greater than $95 \%$ (by NMR).

${ }^{1} \mathrm{H}$ NMR (300MHz, CD 3 OD) $\delta 8.09(\mathrm{~s}, 1 \mathrm{H}), 2.37(\mathrm{~s}, 3 \mathrm{H}), 1.43(\mathrm{~s}, 9 \mathrm{H})$.

${ }^{13} \mathrm{C}$ NMR $\left(125 \mathrm{MHz}, \mathrm{CD}_{3} \mathrm{OD}\right) \delta 152.0,147.1,142.9,141.0,127.9,125.1,61.0$ (heptaplet, $\mathrm{J}=18.7 \mathrm{~Hz}), 35.3,30.4,14.4$.

HRMS (IEA) calculated for $\mathrm{C}_{12} \mathrm{H}_{13} \mathrm{D}_{3} \mathrm{~N}_{2} \mathrm{O}_{5}: 271.1248$, experimental: 271.1248

Preparation of 5-tert-butyl-2,4,6-trinitro-m-xylene-d9 (musk xylene-d9) (8)<smiles>Cc1cccc(C)c1</smiles>

6

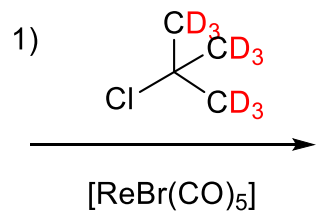

$\left[\operatorname{ReBr}(\mathrm{CO})_{5}\right]$<smiles>Cc1cc(C)cc(C(C)(C)C(C)(C)C)c1</smiles>

7
2) $\mathrm{HNO}_{3} / \mathrm{H}_{2} \mathrm{SO}_{4}$<smiles>Cc1c([N+](=O)[O-])c(C)c([N+](=O)[O-])c(C(C(=O)O)(C(=O)O)C([O-])([O-])[O-])c1[N+](=O)[O-]</smiles>

8

Step 1: In a sealed tube fitted with a stirring bar and under argon, a solution of m-xylene $6\left(0.3 \mathrm{ml}, 2.41 \times 10^{-3} \mathrm{~mol}\right)$ in dry dichloromethane $(6 \mathrm{ml})$ was prepared. Over it, bromopentacarbonylrenium(I) $\left(0.013 \mathrm{~g}, 3.13 \times 10^{-5} \mathrm{~mol}, 0.013 \mathrm{eq}\right)$ and perdeuterated tertbutyl chloride $\left(0.85 \mathrm{ml}, 6.72 \times 10^{-3} \mathrm{~mol}, 2.79 \mathrm{eq}\right)$ were added, in this order. The resulting 
solution was stirred at rt, with the progress of the reaction being monitored by TLC. After 5 days the reaction was complete, after which water was added and the resulting mixture was extracted with ethyl acetate $(3 \times 20 \mathrm{ml})$. The organic phase was dried over anhydrous sodium sulfate, filtered, and concentrated. The residue $(7,0.40 \mathrm{~g})$ was used directly in the next step without further purification.

Step 2: In a round bottom flask fitted with a stirring bar, a mixture of sulfuric acid (0.5 $\left.\mathrm{ml}, 8.86 \times 10^{-3} \mathrm{~mol}, 15 \mathrm{eq}\right)$ and nitric acid $\left(0.4 \mathrm{ml}, 9.48 \times 10^{-3} \mathrm{~mol}, 16 \mathrm{eq}\right)$ was prepared, and then cooled in an ice bath. Crude compound $7\left(0.1 \mathrm{ml}, 5.84 \times 10^{-4}\right.$ moles $)$ was slowly added to the nitrating mixture. After $5 \mathrm{~min}$, the reaction was heated to $80^{\circ} \mathrm{C}$ for $30 \mathrm{~min}$. Then, $5 \mathrm{ml}$ of water/ice were added and the resulting mixture was extracted with dichloromethane $(3 \times 20 \mathrm{ml})$. The organic phase was dried over anhydrous sodium sulfate, filtered, and concentrated. Ethanol was added to the crude reaction residue, which resulted in the crystallization of the desired product as a white solid $(0.070 \mathrm{~g}, 42 \%)$.

${ }^{1} \mathrm{H}$ NMR $\left(300 \mathrm{MHz}, \mathrm{CD}_{3} \mathrm{OD}\right) \delta 2.16(\mathrm{~s}, 6 \mathrm{H})$.

${ }^{13} \mathrm{C}$ NMR $\left(126 \mathrm{MHz}, \mathrm{CD}_{3} \mathrm{OD}\right) \delta 150.3,133.9,124.4,28.1$ (heptaplet, $\mathrm{J}=18.7 \mathrm{~Hz}$ ), 12.0. HRMS (IQA) calculated for $\mathrm{C}_{12} \mathrm{H}_{7} \mathrm{D}_{9} \mathrm{~N}_{3} \mathrm{O}_{6}[\mathrm{M}+1]$ : 307.1604 , found: 307.1597

Preparation of 2,6-dihydroxy-4-methyl-benzaldehyde-d1 (atranol-d1) (11)<smiles>Cc1cc(O)c(C=O)c(O)c1</smiles>

9

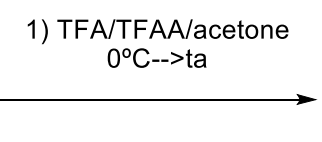

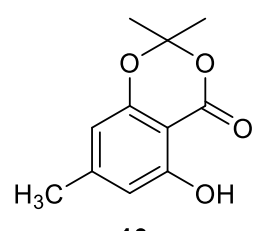

10

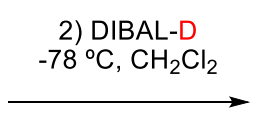<smiles>[2H]C(=O)c1c(O)cc(C)cc1O</smiles>

11

Step 1: In a round-bottom flask fitted with a stirring bar and under argon, a solution of 2,6-dihydroxy-4-methylbenzoic acid 9 ( $\left.1 \mathrm{~g}, 5.9 \times 10^{-3} \mathrm{~mol}\right)$ in TFA (10 ml) was added. The resulting solution was cooled in an ice bath and then trifluoroacetic anhydride $(5 \mathrm{ml}$, $\left.3.5 \times 10^{-2} \mathrm{~mol}, 6 \mathrm{eq}\right)$ and acetone ( $\left.4 \mathrm{ml}, 5.4 \times 10^{-2} \mathrm{~mol}, 9 \mathrm{eq}\right)$ were added. The resulting mixture was stirred at $\mathrm{rt}$, the reaction progress being monitored by TLC. After three days the reaction was complete. The reaction mixture was extracted with ether $(3 \times 30 \mathrm{ml})$ and the organic phase was dried over anhydrous sodium sulfate, filtered, and concentrated. Acetonide $\mathbf{1 0}$ was obtained as a pale-yellow solid, which was used directly in the next reaction without further purification. 
Step 2: $10 \mathrm{ml}$ of dry dichloromethane were added to $1.04 \mathrm{~g}\left(5 \times 10^{-3}\right.$ moles $)$ of acetonide 10 in a round-bottom flask provided with a magnetic stirring bar, and the resulting solution was cooled to $-78^{\circ} \mathrm{C}$ for $15 \mathrm{~min}$. After this time, $22 \mathrm{ml}\left(1.5 \times 10^{-2} \mathrm{~mol}, 3 \mathrm{eq}\right)$ of a solution of DIBAL-D $(0.7 \mathrm{M})$ in toluene were added. After stirring at $-78^{\circ} \mathrm{C}$ for 2 hours, the reaction was stopped by adding a mixture of $0.5 \mathrm{M} \mathrm{DCl}$ and $\mathrm{CD}_{3} \mathrm{OD}(5 \mathrm{ml})$. The resulting suspension was stirred at $\mathrm{rt}$ for $30 \mathrm{~min}$, the phases were then separated and the aqueous phase was extracted with $\mathrm{Et}_{2} \mathrm{O}(3 \times 30 \mathrm{~mL})$. The combined organic phase was dried over anhydrous sodium sulfate, filtered, and concentrated. The residue was purified by column chromatography on silica gel, using a hexane ether (4:2) mixture as an eluant, affording atranol- $d 1$ (11) as a yellow solid $(0.2 \mathrm{~g}, 20 \%)$.

${ }^{1} \mathrm{H}$ NMR (300 MHz, $\left.\mathrm{CD}_{3} \mathrm{OD}\right) \delta 6.16(\mathrm{~s}, 2 \mathrm{H}), 2.23(\mathrm{~s}, 3 \mathrm{H})$.

${ }^{13} \mathrm{C}$ NMR $\left(126 \mathrm{MHz}, \mathrm{CD}_{3} \mathrm{OD}\right) \delta 193.1(\mathrm{t}, \mathrm{J}=28.0 \mathrm{~Hz}), 162.3,150.7,106.9,21.0$.

HRMS (APCI) calculated for $\mathrm{C}_{8} \mathrm{H}_{6} \mathrm{DO}_{3}$ [M-1]: 152.0463, found: 152.0459

Preparation of 3-chloro-2,6-dihydroxy-4-methyl-benzaldehyde-d1 (chloroatranold1) (14)<smiles>Cc1cc(O)c(C(=O)O)c(O)c1</smiles>

9

$\mathrm{SO}_{2} \mathrm{Cl}_{2}$
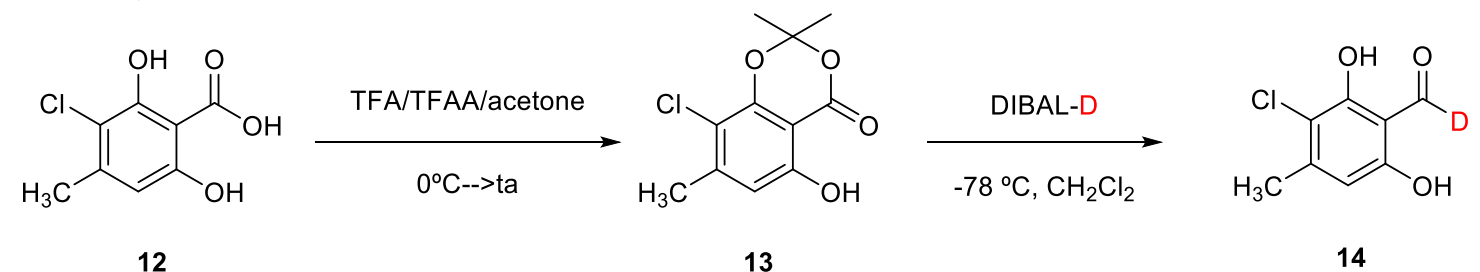

Step 1: In a round bottom flask fitted with a stirring bar, a solution of 2,6-dihydroxy-4methylbenzoic acid $9\left(0.91 \mathrm{~g}, 5 \times 10^{-3} \mathrm{~mol}\right)$ in $\mathrm{Et}_{2} \mathrm{O}(60 \mathrm{ml})$ was prepared. The solution was stirred for 5 minutes, then sulfuryl chloride $\left(0.5 \mathrm{ml}, 5.9 \times 10^{-3} \mathrm{~mol}, 1 \mathrm{eq}\right)$ and ethanol $(0.5 \mathrm{ml})$ were added. The resulting solution was stirred at $\mathrm{rt}$ for $7 \mathrm{~h}$, after which it was concentrated, and the crude reaction product was directly in the next step without further purification. 
Step 2: In a round-bottom flask fitted with a stirring bar, a solution of the crude product from the previous step (12) $\left(1.14 \mathrm{~g}, 5.6 \times 10^{-3} \mathrm{~mol}\right)$ in trifluoroacetic acid (17 ml) was prepared, and then cooled in an ice bath for $15 \mathrm{~min}$. After this time, trifluoroacetic anhydride ( $\left.6 \mathrm{ml}, 4.3 \times 10^{-2} \mathrm{~mol}, 7.6 \mathrm{eq}\right)$ and acetone $(4 \mathrm{ml}, 0.05 \mathrm{~mol}, 9 \mathrm{eq})$ were added. The resulting mixture was stirred at $\mathrm{rt}$, the progress of the reaction being monitored by TLC. After three days the reaction was complete, after which it was concentrated and transferred to a separatory funnel with a saturated aqueous solution of $\mathrm{NaHCO}_{3}$. The mixture was extracted with diethyl ether $(3 \times 30 \mathrm{ml})$. The combined organic phase was washed with brine, dried over anhydrous sodium sulfate, and concentrated to give $0.6 \mathrm{~g}$ of acetonide $\mathbf{1 3}$ as an oil, which was used directly in the next step without further purification.

Step 3: In a round bottom-flask fitted with a stirring bar, a solution of crude acetonide $\mathbf{1 3}$ $\left(0.6 \mathrm{~g}, 2.4 \times 10^{-3}\right.$ moles $)$ in dry dichloromethane $(10 \mathrm{ml})$ was prepared and then cooled to $-78^{\circ} \mathrm{C}$ for $15 \mathrm{~min}$. After this time, $11 \mathrm{ml}(0.007 \mathrm{~mol}, 3 \mathrm{eq})$ of a solution of DIBAL-D (1 $\mathrm{M})$ in dichloromethane were added. After stirring at $-78^{\circ} \mathrm{C}$ for $2 \mathrm{~h}$, the reaction was stopped by adding a mixture of $1 \mathrm{M} \mathrm{DCl}$ and $\mathrm{MeOD}(3 \mathrm{ml})$. The resulting suspension was stirred at $\mathrm{rt}$ for $30 \mathrm{~min}$. Then, the phases were separated and the aqueous phase was extracted with $\mathrm{Et}_{2} \mathrm{O}(3 \times 30 \mathrm{ml})$. The combined organic phase was dried over anhydrous sodium sulfate, filtered and concentrated. The residue was purified by column chromatography on silica gel, using an $\mathrm{Et}_{2} \mathrm{O}$ :pentane (1:4) mixture as eluent, affording chloroatranol- $d 1$ (14) as a greenish oil $(0.12 \mathrm{~g}, 30 \%)$.

${ }^{1} \mathrm{H}$ NMR $\left(500 \mathrm{MHz}, \mathrm{CD}_{3} \mathrm{OD}\right) \delta 6.35(\mathrm{q}, \mathrm{J}=0.7 \mathrm{~Hz}, 1 \mathrm{H}), 2.34(\mathrm{~d}, \mathrm{~J}=0.7 \mathrm{~Hz}, 3 \mathrm{H})$.

${ }^{13} \mathrm{C}$ NMR (126 MHz, CD 3 OD) $\delta 193.2(\mathrm{t}, \mathrm{J}=20 \mathrm{~Hz}), 160.0,157.6,147.4,137.8,110.7$, 108.0, 19.9.

HRMS (APCI) calculated for $\mathrm{C}_{8} \mathrm{H}_{7} \mathrm{ClDO}_{3}[\mathrm{M}+1]$ : 188.0219 , found: 188.0224

\section{Acknowledgements}

Financial support from Ministerio de Economía y Competitividad of Spain (CTQ201784354-P), Xunta de Galicia (GRC 2018/016 and Centro Singular de Investigación de 
Galicia accreditation 2019-2022, ED431G/03) and the European Union (European Regional Development Fund-ERDF) is gratefully acknowledged. 